\title{
A Study on How Development Finance Institutions Support SMEs: A Case Study of International Finance Corporation
}

\author{
Adjei Gyamfi Gyimah ${ }^{1}$ \& Annette Serwaa Agyeman ${ }^{2}$ \\ ${ }^{1}$ Department of Finance, Career Spring Institute, Ghana \\ ${ }^{2}$ Credit Department, Juaben Rural Bank, Ghana \\ Correspondence: Adjei Gyamfi Gyimah, Department of Finance, Career Spring Institute, Ghana.
}

Received: January 5, 2019

Accepted: January 29, 2019

Online Published: February 18, 2019

doi:10.5430/ijfr.v10n2p27

URL: https://doi.org/10.5430/ijfr.v10n2p27

\begin{abstract}
This study sought, inter alia, to establish the role DFIs play in SMEs development and the challenges they face in so doing. The study employed a case study approach with the IFC in focus. The study revealed that DFIs contribute significantly to SMEs growth in various economies through provision of funds, advisory services and raising of capital on international markets even though they are confronted with systemic and non-systemic challenges in so doing. The study feeds into future research on DFIs and SMEs growth while informing policy analysts and policy makers of the way forward in SMEs development.
\end{abstract}

Keywords: DFIs, SMEs, IMF, IFC

\section{Introduction}

Development finance institutions (DFIs) are paramount to the growth of small and medium-scale enterprises (SMEs) in Africa, yet SMEs struggle to access suitable funds to help bolster their operations. These enterprises are also considered to be too small to raise capital from the financial market to finance their activities. The SME sector is a major driver in economic development. They enhance private business growth and entrepreneurial development. SMEs are adaptable and can adjust at short notice to dynamic market demand and supply situations; they increase employment, broaden economic activity and contribute immensely to international trade (Anatal, 2003).

SMEs play an essential role in markets and economies worldwide. For example, in the European Economic Area (EEA) and Switzerland, as many as 16 million enterprises exist with less than one percent being large firms, SMEs make up the remainder. Overall employment in the EEA region is represented by two-thirds SMEs and one-third large corporates (UN, 1999). In Africa, the SME sector is very crucial to growth of the entire continent; according to the Africa Development Bank, the sector contributes more than $45 \%$ to employment and 33\% of GDP on the continent. Ghana since the launch of the Economic Recovery Programme in 1983 has given a significant access to Ghanaian entrepreneurs most of whom operate SMEs - a group that has been largely excluded from previous system of direct control and allocations (Aryeetey et al., 1994).

In spite of all the efforts by governments all over the world to improve and strengthen the contributions of SMEs to the various economies, SMEs continue to face significant challenges especially in Africa. According to the African Development Bank, studies have found that a greater-than 70\% of SMEs don't have access to medium-long term finance, which results in a funding deficit of more than 140 billion US dollars in Africa alone. Efficient local SMEfocused financial institutions usually don't have long-term funds from fund providers across different financial markets which impedes the efficient offering of SME finance in the medium and long-term. Over $60 \%$ of loans advanced to SMEs are to be repaid under one year. Financial institutions also often don't have ample information and systems to evaluate and monitor SME projects. The simple expedient is to employ burdensome and often non-existent collateral.

Another significant challenge facing SME financing is the lack of measurement of investment on SME funds. Various attempts have been made in Europe to measure the impact of financing on SMEs. These attempts include a recent undertaking of the European Investment Bank (EIB) collaborating with six other experts. This Dahlberg report stresses the persistent challenges confronting SMEs in the developing world. Intermediaries as financial institutions operating with the EIB SME lending programmes are expected to extend a financial benefit to the SMEs they deal with and also 
complement with an equivalent sum for lending from their own funds.

It is quite obvious that a great number of SMEs might not possess the traditional collateral needed for bank lending, nor high profitability to attract investors with high risk appetite and venture capital firms. Furthermore, information asymmetry in markets can limit the efficacy of credit scoring and financial statement - based lending. The foregoing is the basis of the supposed finance gap among SMEs in emerging markets (Newberry, Derek 2006). Most countries expend substantially from the public purse to reduce equity and debt gaps that bedevil small firms particularly.

Credit guarantees, interest subsidies and direct loans are some policy interventions which have been established to help moderate credit rationing of SMEs (Casey, 1996; European Commission, 2003a). Several countries have Foreign Direct Investment credit schemes available. The finance gap of SMEs has not been well founded empirically, though it is widely speculated and accepted. The role of developmental financial institutions in supporting SME financial gaps has been a subject for discussions among various academics, international bodies and civil societies. However, not much attention has been paid by academics to the financing decisions of DFIs among SMEs as opposed to big international businesses which dominate related literature (Oviatt and McDougall, 1994; Covelo and McAuley, 1999). A study on DFIs financing decisions in SMEs becomes very crucial.

Consequently, this study was conducted to examine the role DFIs play in supporting SMEs and the related challenges faced by DFIs in dealing with SMEs. The subsequent sections present: review of relevant literature, the research methodology, data analyses, and the conclusion of the entire study.

\section{Literature Review}

\subsection{Development Finance Institutions (DFIs)}

Development Finance Institutions (DFIs) are institutions usually linked to national governments that invest in projects in the private sector with the twin aim of stimulating development in the developing world while staying financial sustainable themselves. DFIs are more pronounced and established in the developed world where their operations and history are well-founded (Dalberg, 2010).

\subsubsection{European DFIs}

The Association of European Development Finance Institutions (EDFI) has fifteen members who operate state-controlled funds with a mandate to invest in emerging markets and the developing world. The European DFIs all have different areas of specialization and expertise, often reflecting the comparative advantages of partners in their home countries. The European DFIs also have diverse investment strategies and operate in various countries, using different investment instruments. Some of them are fully state-owned while others have private participation. The 15 European DFIs are: IFU, SOFID, BIO, Norfund, SIMEST, CDC, BMI-SBI, PROPARCO, COFIDES, DEG, Finnfund, FMO, OeEB, SIFEM, and Swedfund,

\subsubsection{Multilateral DFIs}

Multilateral DFIs are development finance institutions with multiple shareholders from various countries (IFC, 2013). Multilateral DFIs include European Investment Bank (EIB), Asia Development Bank (ADB), International Finance Corporation (IFC), Africa Development Bank (AfDB), European Bank for Reconstruction \& Development (EBRD) and Multilateral Investment Guarantee Agency. In this paper, the International Finance Corporation (IFC) is discussed in detail.

\subsection{International Finance Corporation}

The International Finance Corporation (IFC) is a World Bank Group member, and the largest global development institution focused exclusively on the private sector in developing countries. It helps developing countries achieve sustainable growth by financing private sector investment, mobilising capital in international financial markets and providing advisory services to businesses and governments. In over 100 countries in mostly emerging markets, the IFC has worked with companies and financial institutions which has led to job creation, revenue generation through tax, environmental enhancement and corporate governance improvement, and hence, overall development of local communities (IFC, 2013).

The IFC serves as initiators in poorer, fragile conflict states, where providing finance involves high risk. Their involvement enables development projects to begin, where they otherwise may not or continue when plans may have been abandoned. They also promote socio-economic development by providing the means for governments in developing country, which ends up reducing aid dependency. The IFC also serves as a facilitator to attract and mobilise the involvement of other private investors. The presence of the IFC in a country is a beacon to other development partners. 
In terms of finance, the IFC engages in on-lending facilities to financial institutions which provide loans and education to local SMEs; directly to private enterprises and private sector intermediaries (such as funds of funds) which invest in underlying private enterprises to boost development projects.

Financing is sometimes fashioned as long-term loans (with 10 - 25 years' horizon), credit risk guarantees and equity investments. The IFC also offer technical assistance and advisory by working with governments and other organisations in providing general support as well as financial support for particular projects.

Summarily, the work of the IFC has yielded over $\$ 25$ billion in investments and about 2.7 million jobs. The IFC has also reached out to about 1 million students, 3.1 million farmers, 52.2 million customers and 17.2 million patients (IFC, 2013).

\subsection{Role of DFIs in SMEs Support}

In many economies, DFIs prevent the incidence of a credit crunch with their crucial counter-cyclical role with the expansion of their activities in times when private actors increase their risk aversion thereby deleveraging. It remains challenging as to how to allow DFIs to play a significant role in promoting access to finance without compromising their effectiveness as counter-cyclical policy instruments.

The range of services provided by DFIs is varied. DFIs provide loans or guarantees to investors and entrepreneurs, take equity positions in businesses or investment funds as well as funding for state infrastructure projects. In industrial concerns in economies where collateral requirements stall access to credit from commercial banks, DFIs take the lead in industrial projects. DFIs also actively support micro loans to firms and finance small and medium-size enterprises often viewed as too risky by private fund providers. In such cases, DFIs often find themselves with first-mover advantage in markets with strong growth potential.

To find resources for other projects, DFIs often fall on profits from their existing investments. This approach has been largely successful, with institutions such as the European Bank for Reconstruction and Development (EBRD) or CDC outperforming emerging market indices (Dickinson, 2012). According to a recent INSEAD study, development finance institutions -DFls serve three main functions:

1. Offer long-term debt instruments otherwise not available on the local financial markets

2. Provide risk mitigation, either implicitly through involvement, or explicitly through guarantees or credit enhancement instruments.

3. Offer services to optimize the development impact of projects. (Landrey et al., 2002)

The first two services reflect the institutions willingness to accept both commercial and country risk, while the third is an add-on attempt to ensure socially-responsible outcomes. Adding to this list of functions, it is argued that DFls should serve two other valuable functions. The first is to act as a counter-cyclical buffer to the often whimsical flows of international financial markets (Griffith, 2004) and the second function is to help demonstrate to commercial financiers the viability of banking projects available in their countries. With the implied stability of an equity investment or loan to a local financial institution, DFls try to catalyze other sources of local funding, thereby achieving a multiplier effect. The end goal of most DFls is to graduate as many institutions, borrowers and savers into the formal banking sector as possible; and maximize the participation of local capital in project financing.

\section{Research Method}

This study mainly explored the contribution of DFIs to SME development as well as the challenges that emerge in dealing with SMEs using IFC as a case study. Data was obtained from the IFC and Institute of Economic Affairs (IEA). To maintain the integrity of the research, the following considerations were made. The anonymity of the responding persons was maintained because the names and identities were not to be recorded in this study. The responding institutions were mentioned but only with their collective identity. The issues raised in this study are based on the best judgment and assessments of the potential benefit that a research of this nature would have on the discussions of SME development and the effectiveness of DFIs in supporting SMEs in an economy. 


\section{Presentation of Findings}

4.1 IFC's Role in SMEs Support

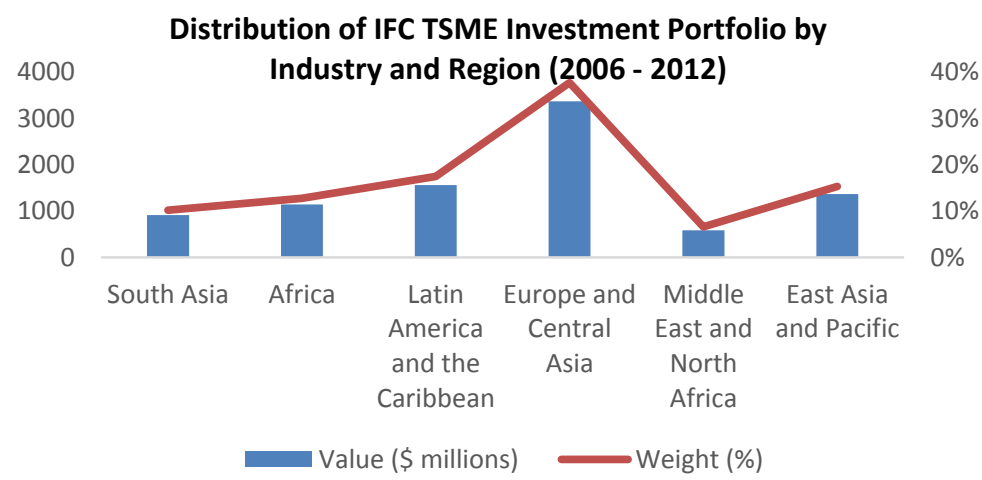

Figure 1. Distribution of IFC TSME investment portfolio by industry and region (2006-2012)

Development finance institutions are risk capital investment funds. The International Finance Corporation is the largest DFI supporting SMEs. Over the period 2006 - 2012, IFC committed US $\$ 8.932$ billion to its SME finance portfolio. As demonstrated in Figure 1 above, the portfolio was regionally distributed as follows: US\$911 million (10 percent) was in South Asia, US \$1,100 million (13 percent) was in Africa, US\$1562 million (17 percent) was in Latin America and Central Asia, US\$3367 million (38 percent) was in Europe and Central Asia, US\$586 million (7 percent) was in Middle East and North Africa and US\$1366 million (15 percent) was in East Asia and Pacific. IFC has had an enduring commitment to the support of SMEs, beginning with the formation of its first project development facility more than 30 years ago, and manifested in its Roadmap for FY14-16. In the past three decades, the IFC has redirected focus from direct assistance to SMEs to indirect assistance to financing SMEs through banking institutions and other financial institutions.

Through its donor-financed project development facilities, IFC commenced provision of direct technical assistance to SMEs in the 1980s, and funding them directly in many places of the world. The technical assistance was custom-made to help SMEs access bank funding by helping SMEs craft sound investable and bankable projects. In parallel with the project development facilities, IFC set up small pools of funds (about \$2.506 million in total) to support direct SME investments mainly in Africa and the East Asia and Pacific.

IFC picked up numerous lessons from its experience in providing direct assistance and financing for SMEs. From a financial standpoint, IFC's experience was disappointing. Although the amounts involved were relatively small, their gross non-accrual rates were much higher than IFC's portfolio as a whole. While recovery of cost was limited; little success was achieved with the project development facilities through which advisory services were offered (Cohn, 2004). Contributions provided were usually very small relative to total program costs; and were only offered by a small segment of clients. The SME clients involved, though enjoyed free technical assistance, were discontented with how deficient many IFC technical consultants were in terms of local knowledge. Another challenge was that while IFC saw these firms as SMEs in the developing world, donors funding these programs saw these firms as large corporates and thus felt jittery giving out their funds. Furthermore, overheads were high for IFC's advisory operations.

In terms of funding SMEs through financial institutions; IFC commenced in 1994, mainly with banks in the Caribbean Region and Latin America. Using its SME focus as justification, IFC's Global Financial Markets Department was able to support banks in middle-income countries, typically IDA countries and frontier markets. A compelling argument made by the IFC was that even in large middle-income countries, frontier markets existed given regional disparities; and that development impact would still be made if investments are made in financial institutions that focus on SMEs in specific areas. Working with financial intermediaries allowed IFC to support far more micro, small and medium-scale enterprises (MSMEs) than it would be able to support on its own, and it enabled IFC to meet its targets on reach indicators such as the number and volume of loans to SMEs. This also improved portfolio performance.

In 2000, IFC launched the Private Enterprise Partnership (PEP) model in the former Soviet Union countries to further deal with the foregoing concerns. This was later extended to other regions. PEP consolidated IFC's existing large 
Advisory Services program in the Commonwealth of Independent States to install a more specialized management structure and to address donor requests for a long-term IFC commitment to the region. PEP management was organized by core product areas; their objective was to deliver Advisory Services in financial markets, corporate governance, business enabling environment, linkages with large firms, and SME development. PEP became a model for a number of multi-donor, regionally focused project development facilities. In recent years, IFC has done much to mainstream facility staff and standardize core products in its advisory services.

One objective of IFC's 2014 - 2016 Roadmap was to employ institution building in developing local financial markets, with a focus on MSMEs in terms of the use of innovative financial products, and mobilization. It emphasizes the job creation potential of SMEs, which "may account for up to four-fifths of job creation and two-thirds of employment in developing countries". This is often used to validate SME interventions by IFC, yet its own jobs study arrives at a much more nuanced conclusion, characterized in the Roadmap as follows:

In general, while MSMEs tend to have higher rates of job growth in developing countries, larger companies provide more sustainable jobs, are typically more productive, offer higher wages and more training, and support a big multiple of the direct jobs they provide through their supply chains and distribution networks (which in particular provide opportunities for the poor) (IFC, 2013).

Many MSMEs fold up and exit markets and therefore; the many jobs created through MSMEs return low net job creation figures in the medium to long term. This perspective is substantiated by longitudinal studies on job creation. The jobs study does not offer a basis to distinguish firms by size apartS from addressing systemic constraints that may disproportionately handicap a particular class of firms' ability to generate employment.

Only some of the key constraints to SMEs will be connected to the Targeted Small and Medium Enterprise (TSME) portfolio, whereas others, such as support for broader financial sector reforms, electric power investments, and regulatory reform, may not. Many of these constraints, though, are addressed through other IFC or Bank Group instruments.

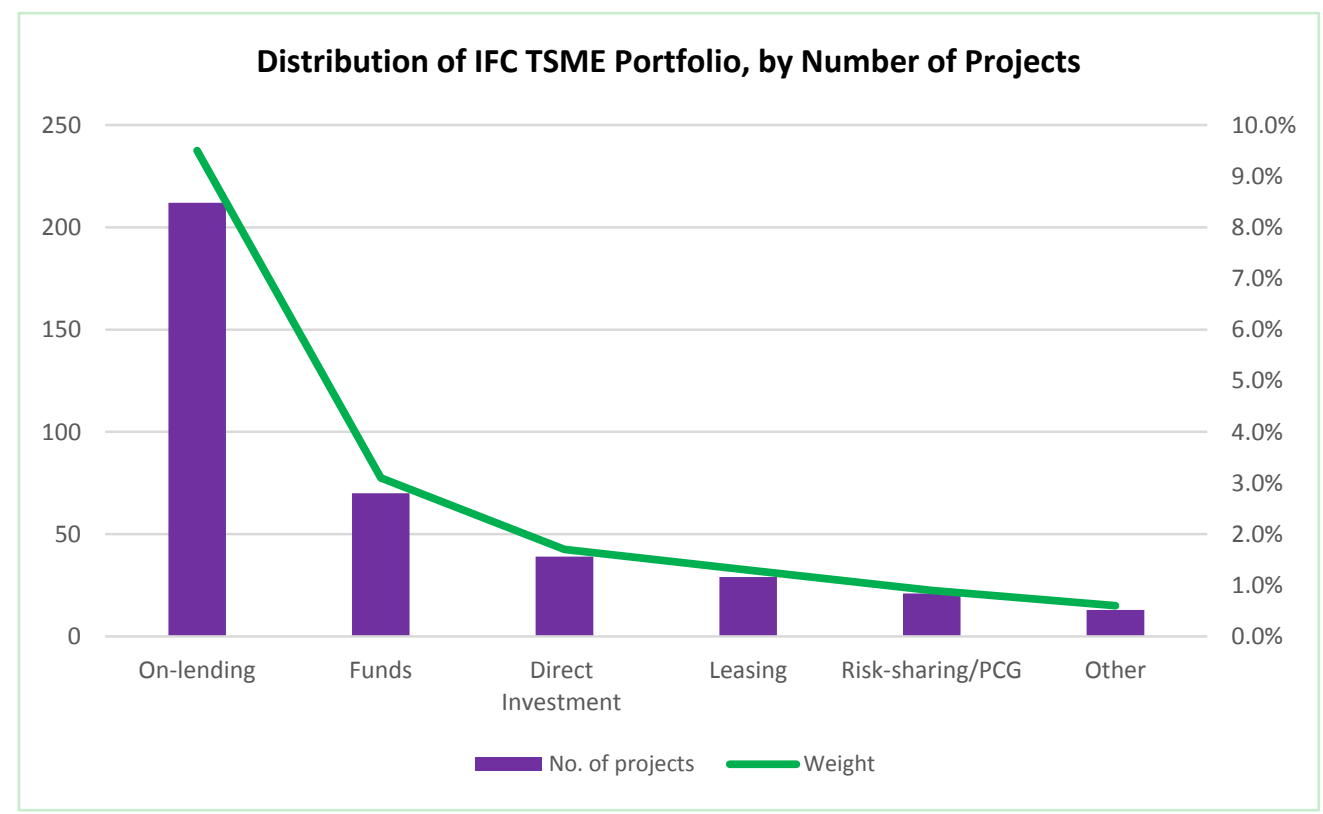

Figure 2. Distribution of IFC TSME portfolio, by number of projects (2006-2012)

Figure 2, which presents a portfolio analysis for sanctioned projects spanning 2006 - 2012, finds that 384 by value and 17 percent of IFC's total portfolio by number of investment projects can be categorised as targeted TSME. Most IFC investments supporting TSMEs for review were mainly indirect. By financing institutions (risk guarantee facilities, funds, banks, and so forth) that support SMEs, IFC has improved the capacity of the financial system, augmented SMEs' access to finance, and built or fortified financial markets in SME financing.

Within this product line (Figure 2), loans to banks accounted for 9.5 percent of projects (representing 55 percent of 
commitments), equity investments in banks accounted for 3.1 percent of projects (representing 18 percent of commitments) and the remaining 1.7 percent of projects (representing 10.2 percent of commitments) were combined loan and equity investment projects. Other significant product lines include equity and venture capital funds aimed at financing SMEs (representing 0.9 percent of targeted SME projects and 3.4 percent of TSME net commitments), partial credit guarantees (representing 0.9 percent of TSME projects and 5.5 percent commitment value), and leasing 1.3 percent of TSME projects (representing 7.6 percent of commitment value).

\subsection{IFC Investment in and Financing of Private Sector}

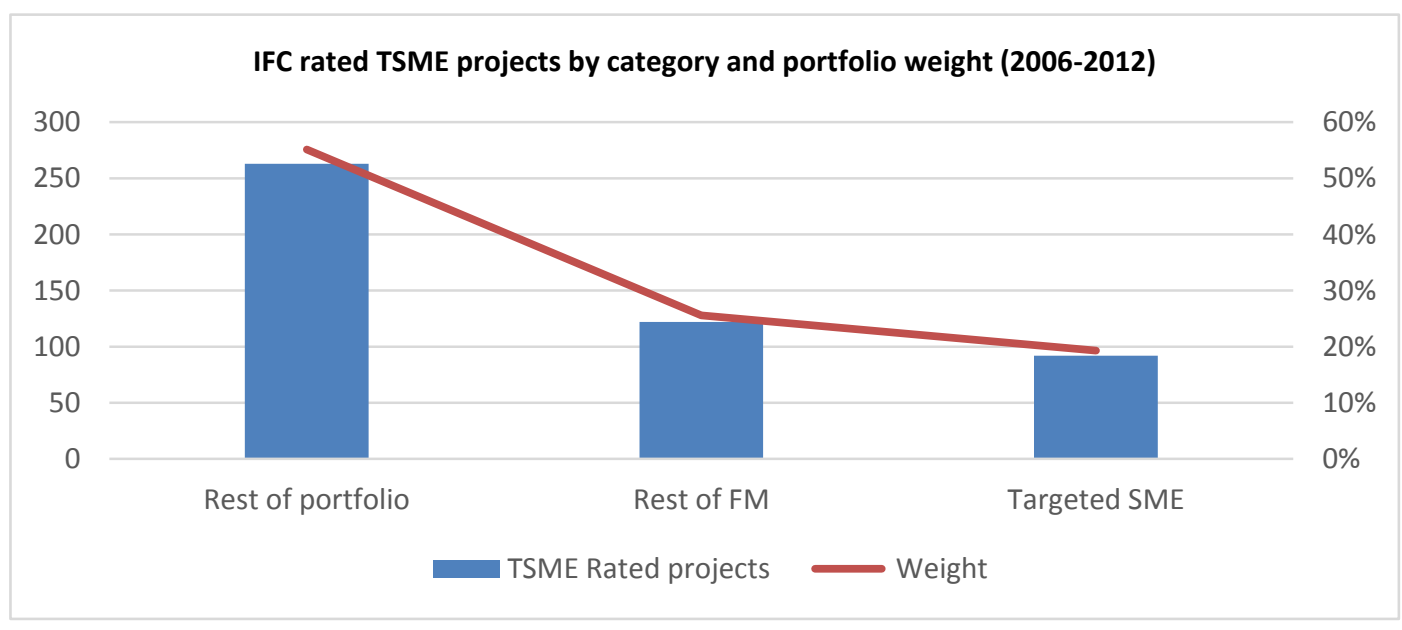

Figure 3. IFC investment portfolio by product category

From Figure 3, the product line which facilitates SME finance through financial institutions, constituted 19 percent of net commitments solely for targeted SME support, 26 percent for FM and 55 percent for rest of portfolio. The IFC operates to enhance SMEs' access to financial services in developing countries. Mezzanine finance, loans and equity as well as funding SME-focused financial institutions are means employed to achieve this. Financial institutions receive training and capacity building as well as awareness on best practices for SME Banking (IFC, 2013).

Through technical assistance and investments, the IFC is able, in the most effective and efficient way, to support financial intermediaries in their bid to reach the SME sector. For SME loans, IFC collected two indicators from banks it financed: non-performing loans, which it collects for all bank finance, and SME loans, generally defined as loans of less than $\$ 1$ million. The SME loans indicator is used to measure how many SMEs have access ("reach") to IFC investments through the intermediaries; and also as a development effectiveness indicator in the Development Outcome Tracking System (DOTS). These "reach" data provide a potentially useful measure of the extent to which IFC clients are reaching SMEs and the extent to which, through them, IFC is also reaching SMEs (IEG, 2013)

For the evaluation of SME loan portfolios, 82 IFC investment projects, which were routed through financial intermediaries to support SMEs, were assessed by IEG. 33 of the projects representing about 40 percent failed to meet their targets for SME financing. Projects fell short of expectations when the SME portfolio decreased in size; the SME portfolio increased in size but had fewer clients (which means larger clients); or the increase in SME financing fell short of targeted portfolio increases. Two fundamental reasons accounted for why projects fell below expectations, namely; a change in strategy of the financial intermediary and the macroeconomic environment. Strategic changes were usually rife among banks. On the hand, inability to meet fundraising targets was the major reason why Funds usually did not meet expectations.

Bank clients are enveloped in secrecy and this has been challenging in estimating the efficacy of IFC interventions through banks. It is, therefore, unclear what impact these investments are having at the firm level and only a few systematic studies have been conducted in this regard.

Between 2006 and 2012, IFC invested $\$ 1.4$ billion in 70 TSME funds. In 2012, the funds strategy of the IFC indicated that increase in employment in frontier regions and springing up of new industries were dependent on investments in small businesses. The strategy further revealed that funds focused exclusively on SMEs yielded lower returns than 
equity funds that invested in a diversified portfolio with an inclusive SME focus. A greater proportion of overall projects are hosted in Sub-Saharan Africa (SSA) and South Asia, with India alone hosting 15 IFC-financed funds while SSA hosts about 43 percent of the regionally focused funds (which spread risk across a group of countries). IFC advises fund managers and mostly sits on the funds' advisory or investment committees.

Over $\$ 1$ billion was invested by 15 TSME fund projects in 196 companies from 2006 to 2012. Investment values were within a band of $\$ 100,000$ to $\$ 2.2$ million. It emerged from an evaluation of the 15 TSME funds that 7 were successful. The success factors were identified as follows:

- $\quad$ fund's focus on its SME strategy (six projects)

- successful transfer of knowledge and development of management and corporate governance to investee companies (five projects) and

- $\quad$ project impact on private sector development (four projects).

Generally, non-TSME funds performed better and were more successful than TSME fund projects over time.

IFC has also noted leasing as highly impactful and potent in affording SMEs term financing for logistic equipment (IFC, 2013).

In leasing, the leased asset serves as collateral and precludes the burden of collateral, which usually impedes SMEs' access to finance. Leasing holds 1.3 percent of total TSME investment projects and 7.6 percent of commitment value.

Between 2006 and 2012, 50 percent of 8 evaluated leasing projects by IFC realised their development objectives. A case in point is Nicaragua where a leasing start-up was financed by the IFC; and was appraised by IEG as moderately satisfactory.

However an unsuccessful rating was ascribed by the IEG to an IFC program earlier which sought to create a leasing legal framework to promote novel leasing regulations or laws. At the end of the IFC projects without a legal framework, the company was challenged with implementing leasing contracts. When IEG, in 2013, embarked on a country visit, the company was closing its leasing operations. The big picture therefore establishes an issue of appropriate sequencing of advisory work and investment.

The key question arises as to whether IFC's approach of going through banks is the most efficient in terms of making a contribution to enhancement of the financial sector in various countries. This consideration is rendered more legitimate by the fact that the SME financing gap far outweighs IFC's financial contribution. In this light, the scarce resources available to the IFC would be concentrated on promoting competitive and sustainable financial markets which would attend to SMEs, especially in poorly served and underdeveloped markets.

\subsection{IFC Advisory Services}

In the last 15 years, IFC's Advisory Services have been overhauled to have better standardisation in business line and a narrow focus. The changing dynamics of the World Bank Group means that IFC has also undergone significant changes in its operations. During the portfolio review period, IFC launched TSME advisory projects, representing expenditures of around $\$ 170$ million (IEG, 2013). Almost 50 percent of these projects represented technical assistance to governments and financial institutions.

36 percent of these projects (97 projects) provided advice to Microfinance, financial institutions and SME Banking.17 percent provided advice to governments: 4 percent each to both Sustainable Energy Finance and Strategic Community Investment and 9 percent to SBA-Other. A quarter of the projects to business development services; nearly another quarter was for linkage products, often focused on upgrading production of suppliers to large firms. Advisory dollars were focused largely on poorer countries (IDA and IDA blend), and 40 percent of expenditures took place in Africa. Fifty-one percent of expenditures focused on small business advisory activities: 36 percent on access to finance, 15 percent on investment climate reforms targeted at SMEs (Table 1). Advisory Services projects often offer a mix of several related product lines. The most prevalent in the 2006 - 2012 TSME portfolio are within the Access to Finance and Sustainable Business Advisory business lines, more specifically the "SME Banking" and "Farmer and SME Training" product lines (Table 1). These two product lines are each present in 30 percent of the 268 TSME projects; the rest are each present in less than 10 percent of projects. 
Table 1. TSME advisory portfolio by business classification

\begin{tabular}{llllll}
\hline & \multicolumn{6}{l}{ TSME Projects } & \multicolumn{2}{l}{ Overall Portfolio } \\
\hline TSME Product Lines & $\begin{array}{l}\text { \% } \\
\text { project }\end{array}$ & $\begin{array}{l}\text { Number } \\
\text { projects }\end{array}$ & $\begin{array}{l}\text { of } \\
\text { Targeted } \\
\text { SME (\%) }\end{array}$ & $\begin{array}{l}\text { Rest } \\
\text { portfolio (\%) }\end{array}$ & $\begin{array}{l}\text { Number } \\
\text { projects }\end{array}$ \\
\hline Farmer and SME Training & 30 & 82 & 72 & 28 & 114 \\
SME Banking & 30 & 81 & 84 & 16 & 97 \\
SBA-Other & 9 & 25 & 16 & 84 & 153 \\
Microfinance & 6 & 16 & 12 & 88 & 132 \\
GEM Access to Finance & 6 & 15 & 75 & 25 & 20 \\
Risk Management & 5 & 14 & 45 & 55 & 31 \\
Business Taxation & 5 & 13 & 16 & 84 & 81 \\
Sustainable Energy Finance & 4 & 12 & 18 & 82 & 65 \\
Strategic Community Investment & 4 & 10 & 20 & 80 & 50 \\
\hline
\end{tabular}

Mostly, projects on Advisory Services are concentrated on interventions that bring value to all scales of businesses, though they may unequally benefit SMEs. In other circumstances, activities are planned to benefit SMEs irrespective of size or scale. For example, 43 projects contain access to finance product line "credit bureaus," of which 4 are specifically targeted to SMEs. Of these four, one project focused entirely on supporting a credit bureau, and the other three combined work on a credit bureau with other SME banking activities. For example, in South Africa, an SME banking project aimed to support and accelerate SME lending by working with financial institutions, credit reporting companies and bureaus, and existing Business Development Services (BDS) providers.

Similarly, a total of 81 projects contain the investment climate product line "Business Taxation," of which 13 (16 percent) are TSME (Table 1). All 13 of these projects combine business taxation activity with other activities such as business regulation (7 projects) and trade logistics (3 projects). For example, in Uzbekistan's SME Policy Development Project IV, business regulation reform accounted for 75 percent of project activities while Business Taxation accounted for the remaining 25 percent (IFC, 2013).

\section{Conclusion}

This study has revealed that DFIs contribute significantly to SMEs growth though they face systemic and non-systemic challenges. Emanating from the study are the following findings: DFIs offer fund management, advisory, project management, leasing, and on-lending services among others to governments, financial institutions and businesses. DFIs impact SME growth indirectly by influencing policies and legislation. There still lingers a systematic weakness in collecting indicators to gauge whether projects are achieving their stated development objectives. For this study, the following measures are recommended to ensure smooth SME growth and coordination with DFIs: Training programs must be intensified to help develop better SME managers and operators; Sound monetary and fiscal policies must be championed by economies to support rather than impede SME growth programs; DFIs must endeavor to tailor global products to suit local needs as much as possible; DFIs must tread cautiously in order not to "crowd out" private players in a well-functioning financial market. Further study could be conducted to cover more years or include more than one DFI to better extrapolate the findings.

\section{References}

Abor, J., \& Quartey, P. (2010). Issues in SME Development in Ghana and South Africa. International Research Journal of Finance and Economics.

AFDB. (2013). The AfDB SME Program Approval: Boosting Inclusive Growth Africa.

Anatal, S. (2002). The UNECE Approach. Internationalization of SMEs, 1-3.

Aryeetey, E. (2005). Informal Finance for Private Sector Development in Sub-Saharan Africa. Journal for African Economics, 6, 161-203.

Bates, J. (1971). The Financing of Small Business. London.

Berger, A., \& Udell, G. (1988). The Economics of Small Business Finance: The Roles of Private Equity and Debt Markets in the Financing Growth Cycle. Journal of Banking and Finance, 22(6), 613-673. 
Chittenden, K., Hall, G., \& Hutchinson, P. (1996). Small Firm Growth, Access to Capital Markets and Financial Structures: Review issues and an Empirical Investigation. Small Business Economics, 8(1), 59-67. https://doi.org/10.1007/BF00391976

Coviello, N., \& McAuley, A. (1999). Internationalization and the Smaller Firm: A Review of Contemporary Empirical Research. Management International Review, 39, 223-256.

Dalberg. (2010). The Growing Role of the Development Finance Institutions in International Development Policy.

Dalberg. (2011). Report on Support to SMEs in Developing Countries Through Financial Intermediaries.

Dickinson, T. (2012). Development Finance Institutions: Profitability Promoting Development.

Eberhard, A. (2008). Underpowered: The State of the Power Sector in Sub-Saharan Africa. Background paper, Africa Infrastructure Country Diagnostics (AICD), World Bank.

EDFI. (2010). Development Finance Explained.

European Commission. (2003a). Observatory of European SMEs, Internationalization of SMEs.

European Commission. (2003b). Observatory of European SME, SMEs and Access to Finance.

Haddan, M., \& Harrison, A. (1993). Are There Positive Spillover Effects from Direct Foreign Investment? Evidence from Panel Data for Morocco. Journal of Development Economics, 42, 51-74. https://doi.org/10.1016/0304-3878(93)90072-U

Hall, B. (1992). Investment and R\&D at the Firm's Level: Does the Source of Financing Matter?. Department of Economics Working Paper (pp. 92-194). University of California, Berkeley.

Harrison, A., \& Mcmillan, M. (2003). Does Direct Foreign Investment Affect Domestic Credit Constraints?. Journal of International Economics, 61, 73-100. https://doi.org/10.1016/S0022-1996(02)00078-8

IFC. (2009). The SME Banking Knowledge Guide.

IFC. (2010). Expanding Financial Services in Africa.

IFC. (2013). The IFC and Development Finance Institutions. Presentation to University of Ghana Business School.

Independent Evaluation Group (IEG). (2013). Assessing the Monitoring and Evaluation Systems of IFC and MIGA, Bennial Report on Operations Evaluation. The World Bank.

Kayanula, D., \& Quartey, P. (2000). The Policy Environment for Promoting Small and Medium-Sized Enterprises in Ghana and Malawi, Finance and Development Research Programme. Working Paper Series, Paper No 15, IDPM, University of Manchester.

Landry, R., Amara, N., \& Lamari, M. (2002). Does Social Capital Determine Innovation? To What Extent?. Technological Forecasting and Social Change, 69, 681-701. https://doi.org/10.1016/S0040-1625(01)00170-6

OECD. (2006). Promoting Pro-poor Growth Private Sector Development.

OECD. (2006). The SME Financing Gap.

OECD. (2009). DAC List of ODA Recipients.

Page, J., \& Söderbom, M. (2012). Is Small Beautiful? Small Enterprise, Aid and Employment in Africa. UNU WIDER Working Paper 94.

S\&P. (2010). Sovereign ratings.

Siegesmund, P., \& Glisovic, J. (2011). Estimating Funder Support for Small and Medium Enterprises (SMEs). Washington, DC: CGAP.

UN. (2009). The Millennium Development Goals Report. United Nations.

UNCTAD. (2004). ICT as an Enabler for Growth. Development and Competitiveness.

World Bank and IEG. (2009). Doing Business: An Independent Evaluation.

World Bank. (2004). Easing Policy Risks, Costs and Barriers to Competition - Keys to Faster Growth, Less Poverty. World Development Report 2005.

World Bank. (2009). Global Monitoring Report.

World Bank. (2010). Africa's Golden Moment Has Come. Says World Bank Vice President for Africa. 